Original Article

\title{
EVALUATION OF ANTI-CML ACTIVITY OF METHANOL AND AQUEOUS EXTRACTS OF BENKARA MALABARICA (LAM.) TIRVENG PLANT LEAVES
}

\author{
KALUBAI VARI KHAJAPEER, RANJAN BISWAL, RAJASEKARAN BASKARAN*
}

Department of Biochemistry and Molecular Biology, School of Life Sciences, Pondicherry University, Puducherry, India 605014 Email: baskaran.rajasekaran@gmail.com

Received: 04 Feb 2018 Revised and Accepted: 11 Apr 2018

\section{ABSTRACT}

Objective: To investigate the phytoconstituents and in vitro cytotoxicity of methanol (MeOH) and aqueous (AQE) extracts of Benkara malabarica (Lam.) Triveng (BM) plant leaves.

Methods: Gas chromatography-mass spectrometry (GC MS) was carried out to disclose the principal phytoconstituents present in MeOH and AQE extracts of $B M$. In vitro cytotoxicity of $B M$ extracts were determined by 3-(4,5-Dimethylthiazol-2-yl)-2,5-diphenyltetrazolium bromide (MTT) assay. Acridine orange (AO)/ethidium bromide (EB) and 4', 6-diamidino-2-phenylindole (DAPI) staining were performed to visualize morphological changes upon treatment of $B M$ extracts. Fluorescence-activated cell sorting (FACS) was carried out to determine the apoptosis and cell cycle arrestability of $B M$ extracts.

Results: GC MS analysis reported the presence of nine phytoconstituents in MeOH and AQE extracts of $B M$. The IC ${ }_{50}$ of $B M$ MeOH, AQE extracts treated K562 cells were $49.78 \pm 1.697,15.47 \pm 1.19 \mu \mathrm{g} / \mathrm{ml}$ for $48 \mathrm{~h}$ and found to be statistically significant ( $p<0.001)$. A0/EB and DAPI staining results anticipated the induction of apoptosis and DNA fragmentation upon treatment of $B M$ extracts. FACS analysis revealed the SubG ${ }_{0}$ cell populations increased in K562 cells treated by BM MeOH (18.15) and AQE (51.26) extracts.

Conclusion: The results of the present study uncovered that the BM AQE extract was more potent in inhibiting K562 cell proliferation through cell cycle arrest and apoptosis compared to the $\mathrm{MeOH}$ extract of $B M$.

Keywords: Phyto-constituents, Cytotoxicity, Benkara malabarica, GC MS analysis and K562 cells

(C) 2018 The Authors. Published by Innovare Academic Sciences Pvt Ltd. This is an open access article under the CC BY license (http://creativecommons.org/licenses/by/4.0/) DOI: http://dx.doi.org/10.22159/ijpps.2018v10i5.25138

\section{INTRODUCTION}

Medicinal plants are extensively used all over the world as folk medicine because they are cost-effective and inexpensive alternative sources of drugs due to their less side effects [1-3]. Plants are a rich source of secondary metabolites such as flavonoids, carotenoids, phenols, alkaloids, terpenoids, saponins and steroids. These secondary metabolites of plant origin have exhibited antimicrobial, antioxidant and anticancer activities [4, 5]. According to World Health Organization (WHO) reports, approximately $65-80 \%$ of the world population use traditional medicine to treat various diseases. Interestingly, $50 \%$ of all modern clinical drugs are of natural product origin [6-8].

Chronic myeloid leukemia (CML) is a hematoproliferative neoplasm that is marked by uncontrolled myeloid cell divisions in bone marrow. The hallmark of CML is the presence of shortened Philadelphia chromosome $(\mathrm{Ph})$ which arises due to a reciprocal translocation between chromosome 9 and chromosome 22 [(9;22) (q34;q11)], leading to the creation of bcr-abl oncogene. This bcr-abl oncogene encodes a constitutively activated tyrosine kinase, BCR-ABL. The catalytically activated kinase, in turn, activates multiple cell proliferatory signalling pathways such as RAS, a small GTPase, mitogen-activated protein kinase (MAPK), signal transducers and activator of transcription (STAT) and phosphoinositide-3-kinase (PI3K) pathways [9-12]. Tyrosine kinase inhibitors (TKIs) like imatinib [13], nilotinib, dasatinib, bosutinib [14] and ponatinib [15] were approved by the US Food and Drug Administration (FDA). TKIs have changed the clinical course of CML; however, mutations in bcr-abl and multi-drug resistance (MDR) due to efflux of the drug because of overexpression of p-glycoprotein (p-gp) make TKIs less effective. Hence, there is a need for an alternative strategy to develop new BCR-ABL inhibitors. Clearly, natural products obtained from plants offer an alternate, effective and inexpensive source for CML therapy [16].

K562 is a BCR-ABL positive CML cell line that was established from a 53 -year-old woman with CML. After 176 passages in $3.5 \mathrm{y}$, the K562 cell line still has active CML cells in blast crisis stage with $\mathrm{Ph}[17,18]$. In the present study, the in vitro cytotoxicity of Benkara malabarica (Lam.) Tirveng (BM) extracts were evaluated against K562 cells. Previous reports suggest that $B M$ leaf and bark extracts reported anti-bacterial and anti-fungal activities [19]. $B M$ methanol $(\mathrm{MeOH})$ root extract had reported anti-convulsant activity against isoniazide induced convulsion in in vivo models [20].

\section{MATERIALS AND METHODS}

\section{Chemicals and reagents}

All the chemicals and reagents used in this work were purchased from Hi-media Pvt. Ltd, Bombay, India.

\section{Cell culture}

K562 cell line was obtained from the National Centre for Cell Sciences (NCCS), Pune and were maintained in RPMI medium ( $\mathrm{pH}$ 7.4) supplemented with $10 \%$ fetal bovine serum (FBS) and antibiotics (100 U/ml penicillin and $100 \mu \mathrm{g} / \mathrm{ml}$ streptomycin) at 37 ${ }^{\circ} \mathrm{C}$ in a humidified $5 \% \mathrm{CO}_{2}$ atmosphere.

\section{Collection and identification of plant material}

$B M$ plant leaves were collected inside the Pondicherry University campus. The plant sample was identified and authenticated by Dr. N. Ayyappan, French Institute of Pondicherry (IFP), Puducherry. BM herbarium specimen was deposited at IFP with accession number HIFP27056.

\section{Preparation of $B M$ extracts}

$100 \mathrm{~g}$ of $B M$ leaf powder was extracted with both $500 \mathrm{ml}$ of $\mathrm{MeOH}$ and water (AQE) using soxhlet apparatus. Extract solution was then filtered through Whatman No.1 filter paper and concentrated using rota-vapour. The concentrated $B M$ extracts were stored at $4^{\circ} \mathrm{C}$ until further use. 


\section{Estimation of total phenolic content (TPC)}

$\mathrm{MeOH}$ and $\mathrm{AQE}$ extracts of $B M$ in the concentration (conc.) range of 40-200 $\mu \mathrm{g}$ were taken and adjusted to $20 \mu \mathrm{l}$ with distilled water. Then, $50 \mu \mathrm{l}$ of Folin-Ciocalteu (FC) reagent (1/10 dilution) was added and incubated for $5 \mathrm{~min}$ at room temperature (RT). This was followed by the addition of $50 \mu$ of sodium carbonate solution $(7.5$ $\%)$. The absorbance was measured at $760 \mathrm{~nm}$. Gallic acid was used as a standard for the calibration curve. The TPC was expressed as gallic acid equivalents (GAE) [21].

\section{Estimation of total flavonoid content (TFC)}

TFC of the $B M$ plant extracts was determined by the aluminium chloride method as described [22]. $\mathrm{MeOH}$ and $\mathrm{AQE}$ extracts of $B M$ of varying conc. (40-200 $\mu \mathrm{g})$ were taken and was made up to $10 \mu \mathrm{l}$ with the solvent ( $\mathrm{MeOH}$ and Distilled water). Then, $30 \mu \mathrm{l}$ of sodium nitrite $(0.03 \%)$ was added and incubated for $5 \mathrm{~min}$ at RT followed by the addition of $30 \mu \mathrm{l}$ of aluminium chloride $(10 \%)$ solution. Incubation was carried for $5 \mathrm{~min}$ at RT and $200 \mu \mathrm{l}$ of $1 \mathrm{mmol}$ sodium hydroxide was added. The total volume was then made up to $1000 \mu \mathrm{l}$ with distilled water and the absorbance was measured at $510 \mathrm{~nm}$. Various conc. of standard quercetin was used to make a standard calibration curve. TFC was expressed as quercetin equivalents (QE).

\section{Gas chromatography-mass spectrometry (GC MS) analysis}

GC MS analysis of $\mathrm{MeOH}$ and $\mathrm{AQE}$ extracts of $B M$ was carried out using Clarus 500 Perkin-Elmer (auto system XL) of as previously described [23]. Using MS data library on a National Institute of Standards and Technology (NIST) Ver.2.1 and comparing the spectrum obtained through GC MS revealed compounds present in the $B M$ extracts.

3-(4,5-dimethylthiazol-2-yl)-2,5-diphenyltetrazolium bromide (MTT) assay

K562 cells were plated in a 96-well tissue culture plates at a density of approximately 5,000 cells per well. The cells were then incubated with $100 \mu \mathrm{l}$ of $\mathrm{MeOH}$ and $\mathrm{AQE}$ extracts of $B M$ in the conc. range $(2,4,8,16,32$ and $64 \mu \mathrm{g}$ ) for $48 \mathrm{~h}$. Untreated cells were used as a control and blank wells containing $100 \mu \mathrm{l}$ of medium only. After $48 \mathrm{~h}$ of incubation, $20 \mu \mathrm{l}$ of the MTT reagent $(5 \mathrm{mg} / \mathrm{ml})$ was added to each well and the plate was incubated for $4 \mathrm{~h}$ at $37^{\circ} \mathrm{C}$. Then the plate was centrifuged at $1500 \mathrm{rpm}$ for $5 \mathrm{~min}$. The supernatant was discarded and to the pellet $150 \mu \mathrm{l}$ of dimethyl sulphoxide (DMSO) was added to each well and absorbance was read at $595 \mathrm{~nm}$ using Aspinco biotech Elisa plate reader [24].

\section{Acridine orange (AO)/ethidium bromide (EB) staining}

Approximately $1 \times 10^{5} \mathrm{~K} 562$ cells were seeded in 6-well tissue culture plate. Cells were then treated with $\mathrm{IC}_{50}$ conc. of $B M \mathrm{MeOH}$ and AQE extracts for $48 \mathrm{~h}$. After $48 \mathrm{~h}$ of treatment, cells were harvested and washed once with phosphate buffer saline (PBS) ( $\mathrm{pH}$ 7.4) and stained with AO/EB $(1 \mu \mathrm{g} / \mathrm{ml})$ for $10 \mathrm{~min}$. The stained cells were then examined under a Nikon Eclipse Ti fluorescence microscope
(Nikon Instruments Inc., NY, USA) using a UV filter (450-490 nm). Untreated cells were used as control [25].

\section{4',6-diamidino-2-phenylindole (DAPI) staining}

Approximately $1 \times 10^{5} \mathrm{~K} 562$ cells were seeded into 6-well tissue culture plates. Then, the cells were treated with $\mathrm{IC}_{50}$ conc. of $\mathrm{MeOH}$ and $\mathrm{AQE}$ extracts of $B M$ for $48 \mathrm{~h}$ following which cells were harvested and washed once with PBS (pH 7.4) and fixed with $4 \%$ paraformaldehyde for 30 min. The fixed cells were stained with DAPI $(1 \mu \mathrm{g} / \mathrm{ml})$ for $10 \mathrm{~min}$ examined under a Nikon Eclipse Ti fluorescence microscope (Nikon Instruments Inc., NY, USA) using a UV filter (450-490 nm). Untreated cells were used as control [26]

\section{Cell cycle analysis}

Briefly, $1 \times 10^{6} \mathrm{~K} 562$ cells were seeded in 6 well plates and treated with the IC 50 conc. of $B M$ extracts for $48 \mathrm{~h}$ at $37^{\circ} \mathrm{C}$. Subsequently, cells were harvested, washed with ice-cold PBS and fixed in $70 \%$ ethanol at $4{ }^{\circ} \mathrm{C}$ for overnight. The fixed cells were then incubated with $0.5 \mathrm{ml}$ of propidium iodide (PI) $(50 \mu \mathrm{g} / \mathrm{ml})$ solution containing triton X-100 $(0.1$ $\%)$, sodium citrate $(0.1 \%)$ and RNase-A $(25 \mu \mathrm{g} / \mathrm{ml})$ for $10 \mathrm{~min}$ under the dark. The percentage of cells in various phases of the cell cycle was assessed in a BD FACS CALIBUR instrument $[27,28]$.

\section{Statistical analysis}

All experiments were carried out in triplicates. The values are represented as a mean \pm standard deviation (SD). $\mathrm{IC}_{50}$ values of $B M$ extracts in MTT assay were determined using non-linear regression employing GraphPad prism software. MTT results were analysed using a one-way analysis of variance (ANOVA) followed by Tukey's multiple comparisons tests where $p$ value $<0.001$ took as significant using SPSS software.

\section{RESULTS AND DISCUSSION}

\section{TPC and TFC}

Phenols and flavonoids are among the most widely occurring secondary metabolites present in plants. Phenols are aromatic compounds which contain one or several hydroxyl groups directly attached to the benzene ring. Phenolic compounds exhibit antioxidant, anti-mutagenic and anti-cancer activities [29, 30]. TPC in $B M$ extracts was deduced from the standard curve of gallic acid (fig. $1 \mathrm{~A})\left(\mathrm{Y}=0.017 \mathrm{x}-0.004\right.$ and $\left.\mathrm{R}^{2}=0.990\right)$. The TPC content of $\mathrm{MeOH}$ and $\mathrm{AQE}$ extracts of $B M$ had contained 238.5 and $312 \mu \mathrm{g} / \mathrm{mg}$ of GAE (fig. 1B). Flavonoids belong to polyphenolic compounds which are prevalent in plants. They contain two phenyl rings A, B and a heterocyclic ring $\mathrm{C}$ (commonly referred to as a C6-C3-C6 skeleton). Flavonoids exhibit antioxidant, anti-inflammatory, antibacterial, antiviral and anticancer activities [31,32]. The TFC in $B M$ extracts was derived from the standard curve of quercetin $\left(\mathrm{Y}=0.002 \mathrm{x}-0.000\right.$ and $\mathrm{R}^{2}$ $=0.989$ ) (fig. 2A). TFC content of $\mathrm{MeOH}$ and $\mathrm{AQE}$ extracts of $B M$ was found to be 798.5 and $333 \mu \mathrm{g} / \mathrm{mg}$ of QE (fig. 2B).

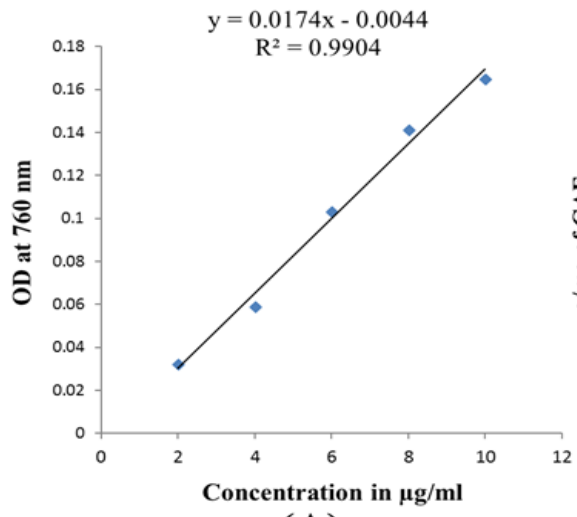

(A)

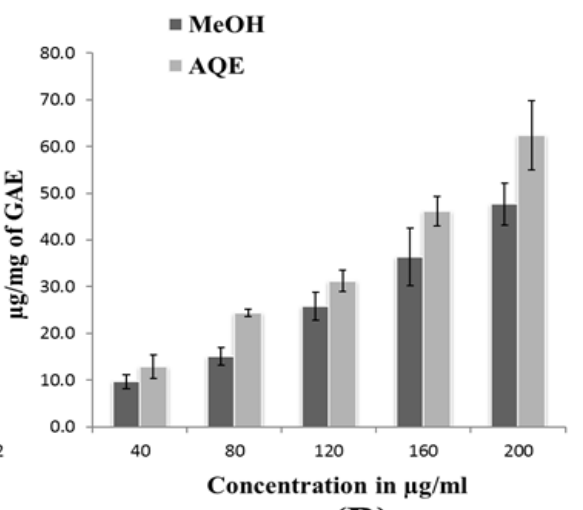

(B)

Fig. 1: TPC of $B M$ extracts, A): Standard curve for gallic acid. B): TPC of MeOH and AQE extracts of $B M$. TPC was more in AQE compared to $M e O H$ extract of $B M$. Values were represented as mean $\pm S D(n=3)$ 


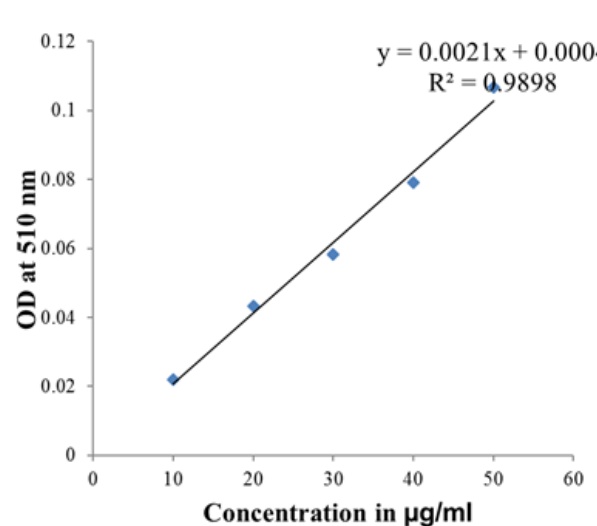

(A)

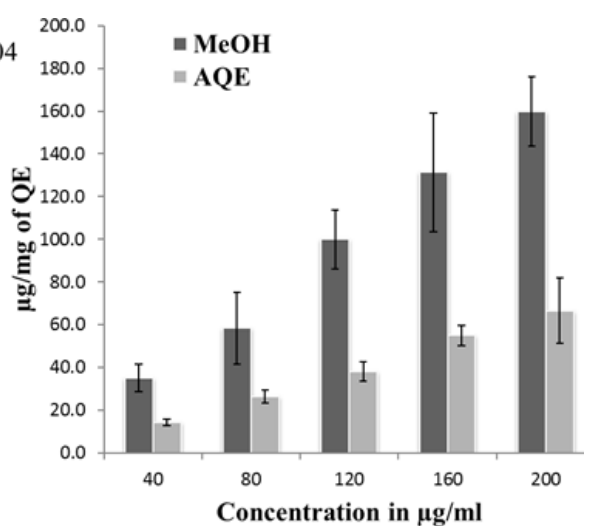

(B)

Fig. 2: TFC of $B M$ extracts, A): Standard curve for quercetin. B): TFC of MeOH and AQE extracts of $B M$. TFC was more in MeOH compared to $A Q E$ extract of $B M$, values were represented as mean $\pm S D(n=3)$

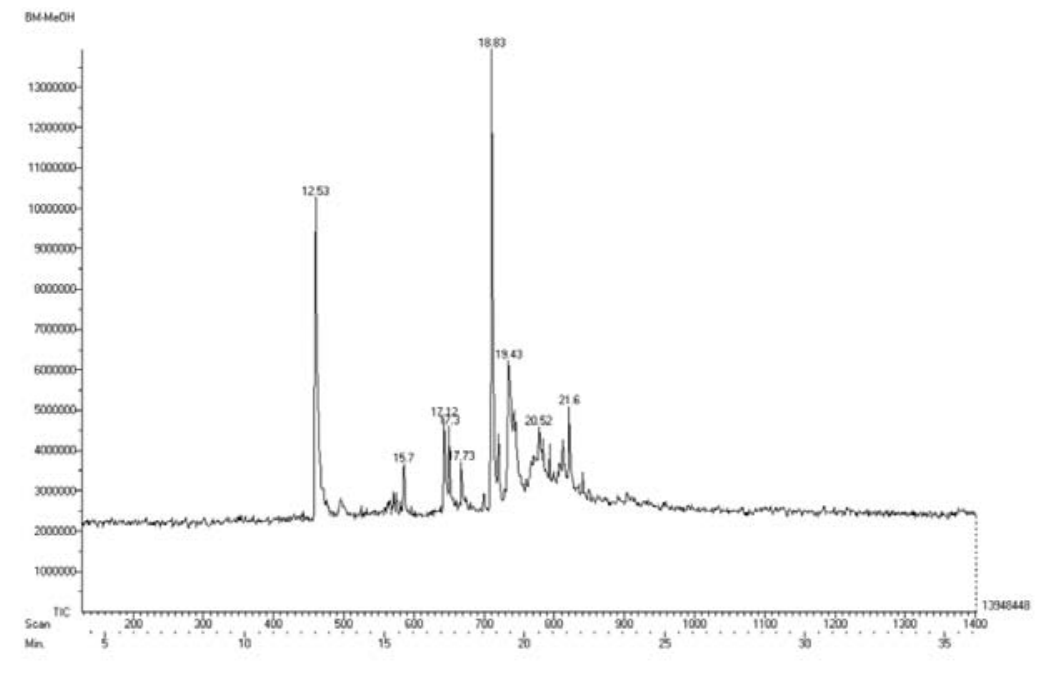

(A)

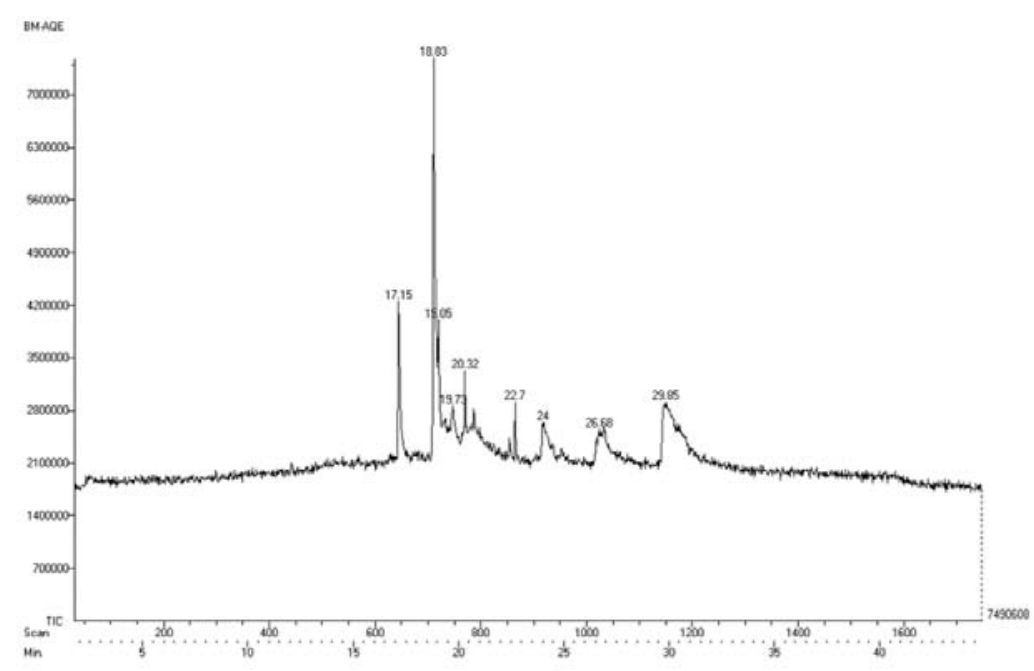

(B)

Fig. 3: GC MS chromatograph of $B M$ extracts, A): GC MS chromatograph of $B M$ MeOH extract showed various compounds at major peaks like 18.83-9-Octadecenoic acid [Z]-, methyl ester, 12.53-phenol,2,4-bis[1,1-dimethylethyl]-, 19.43-2-methyl-Z,Z-3,13-0ctadecadienol and 21.6-benzene1,1-1'-[1-(2,2-dimethyl-3-butenyl)-1,3-propanediyl]bis-were present. B): GC MS chromatograph of BM AQE extract major peaks at 18.83, 17.15, 20.32 and 22.7 corresponds to 10-octadecenoic acid methyl ester, hexadecanoic acid methyl ester, Isopropyl stearate and 2-Cyclohexen-3,6-diol-1-one,2-tetradecanoyl 


\section{GC MS analysis}

GC MS analysis was based on the computer evaluation of mass spectra of samples through NIST based software, direct comparison of peaks and retention time with those of standard compounds and computer matching with the NIST library. Both $\mathrm{MeOH}$ (fig. 3A) and AQE extract (fig. 3B) of $B M$ showed nine important phytoconstituents.

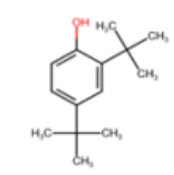

(A)

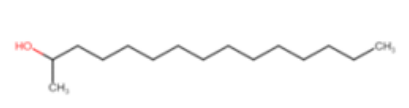

(B)

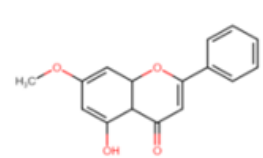

(C)

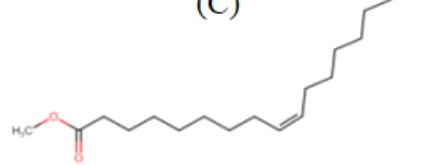

(E)

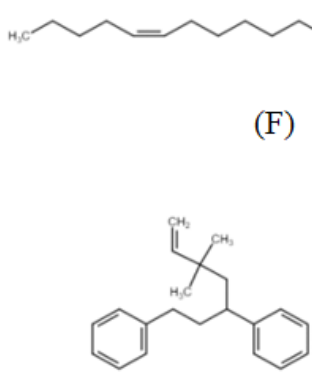

(H)

F)

(D)

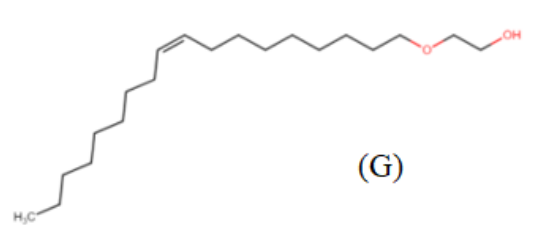

Fig. 4: List of phyto-constituents identified in GC MS chromatograph of MeOH extract of $B M, A$ ): Phenol,2,4-bis[1,1-dimethylethyl], B): 2hexadecanol, C): 4H-1-Benzopyran-4-one,5-hydroxy-7-methoxy-2-phenyl, D): 11-Tricosene, E): 9-Octadecenoic acid [Z]-, methyl ester, F): 2-methyl-Z,Z-3,13-Octadecadienol, G): Ethanol,2-(9-octadecenyloxy) [Z]-, H): Benzene1,1-1-[1-(2,2-dimethyl-3-butenyl)-1,3propanediyl]bis-and I): Quinoline-4-carboxylic acid, 2-(4-isopropylphenyl)

Various phytoconstituents present in $\mathrm{MeOH}$ and $\mathrm{AQE}$ extracts of $B M$ were illustrated in fig. 4 and fig. 5 .

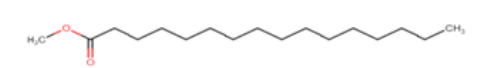

(A)

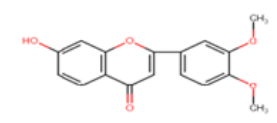

(C)

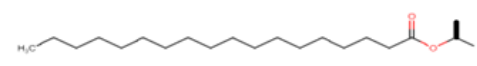

(E)

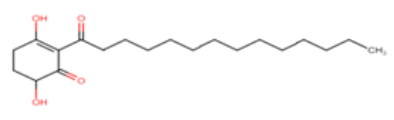

(G)

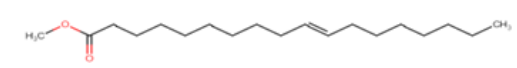

(B)

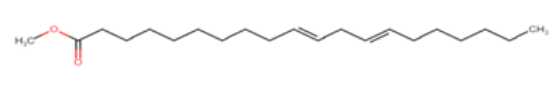

(D)

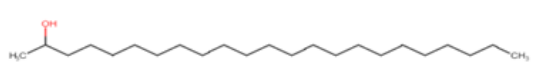

(F)

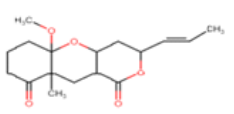

(H)

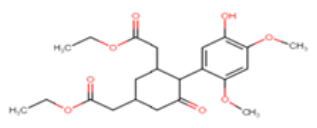

(I)

Fig. 5: List of phyto-constituents identified in GC MS chromatograph of AQE extract of BM, A): Hexadecanoic acid methyl ester, B): 10Octadecenoic acid methyl ester, C): 4H-1-Benzopyran-4-one,2-[3,4-dimethoxyphenyl]-7-hydroxy, D): 10,13-Eicosadienoic acid, methyl ester E): Isopropyl stearate, F): Tricosan-2-ol, G): 2-Cyclohexen-3,6-diol-1-one,2-tetradecanoyl, H): Pyrano[4,3-b]benzopyran-1,9dione,5a-methoxy-9a-methyl-3-[1-propenyl]perhydro-and I): Cyclohexan-1-one-3a,5a diacetic acid,2a(-5 hydroxy-2,4-dimethoxyphenyl)diethyl ester 


\section{MTT assay}

MTT assay was performed to determine the cytotoxicity of $B M$ $\mathrm{MeOH}$ and AQE extracts (fig. 6) against K562 cells for $48 \mathrm{~h}$. Both $B M$ extracts decreased K562 cell proliferation in a dose- dependent manner. The $\mathrm{IC}_{50}$ of $\mathrm{MeOH}$ and $\mathrm{AQE}$ extracts of $B M$ was found to be $49.78 \pm 1.697$ and $15.47 \pm 1.19 \mu \mathrm{g} / \mathrm{ml}$ respectively. The results of our assay revealed that AQE extract was more potent than the $\mathrm{MeOH}$ extract in reducing the $\mathrm{K} 562$ cell proliferation.

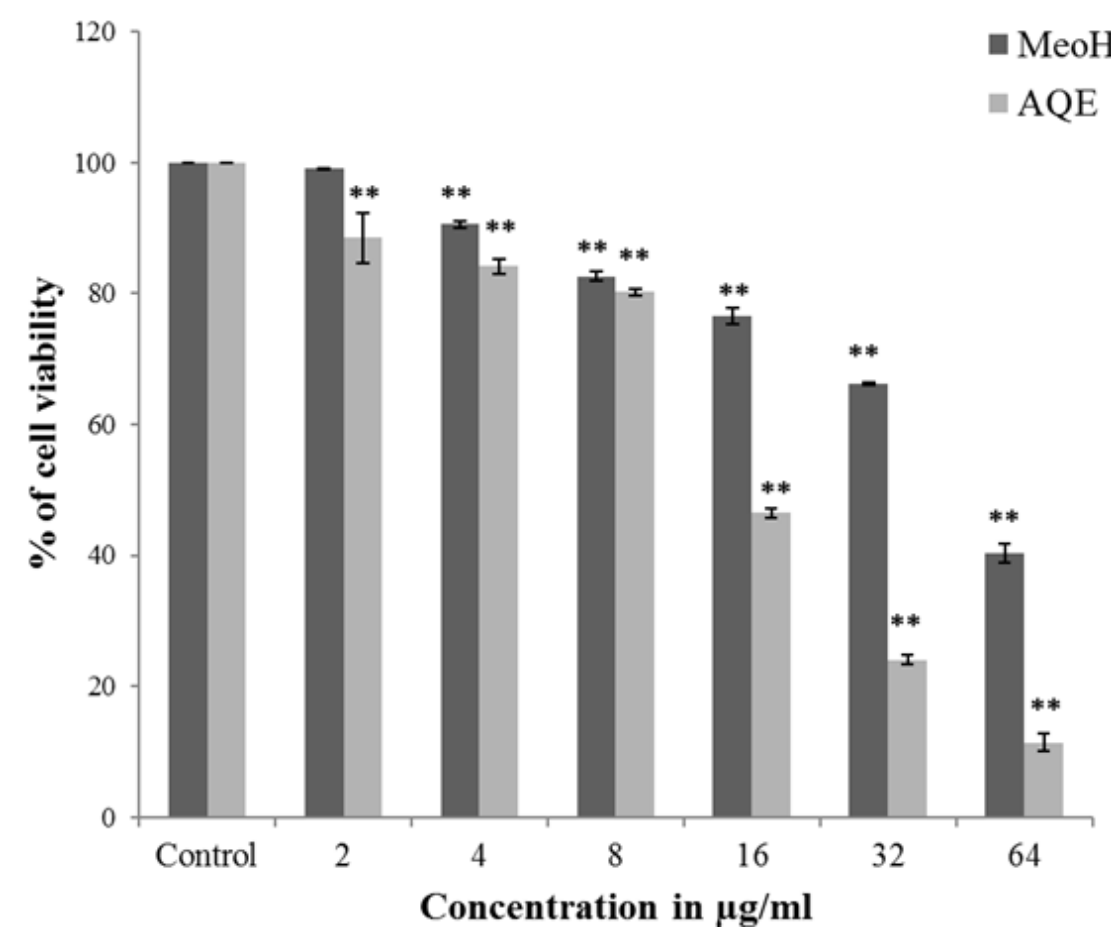

Fig. 6: MTT assay of $B M$ extracts treated $\mathrm{K} 562$ cells for $48 \mathrm{~h}$, values were represented as mean \pm SD (n=3). Statistical analysis of the experimental results was performed using ANOVA followed by Tukey's multiple comparisons to control in which $* *$ represent $p<0.001$ took as significant

\section{A0/EB staining}

Nuclear changes and apoptotic body formation are a characteristic feature of apoptosis, which can be visualized by A0/EB staining [33]. K562 untreated cells appear uniformly green, whereas dead cells appear orange in colour. AQE extract of $B M$ (fig. 7C) was more potent in inducing cell death in $\mathrm{K} 562$ cells compared to the $\mathrm{MeOH}$ extract-treated cells (fig. 7B).

\section{DAPI staining}

Blue-fluorescent DAPI stain preferentially binds to the AT-rich regions of the minor groove of double-stranded (ds) DNA [34]. Binding of DAPI to dsDNA (resulting from DNA defragmentation) increase approximately 20-fold fluorescence enhancement, which was evident in the AQE treated $\mathrm{K} 562$ cells (fig. 7F) compared to $\mathrm{MeOH}$ extract (fig. 7E). Morphological changes observed in the treated cells displayed broken nuclei as discrete fragments.

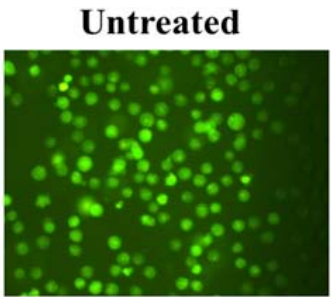

(A)

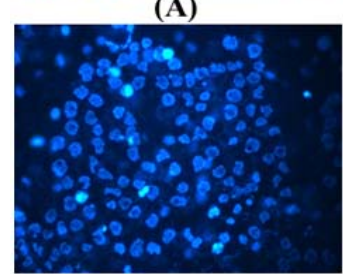

(D)

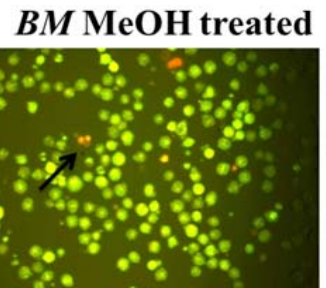

(B)

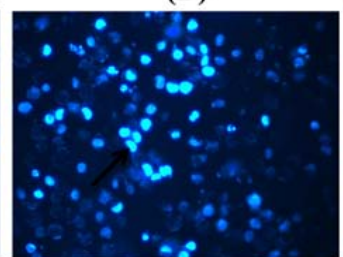

(E)

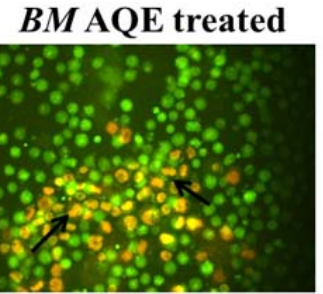

(C)

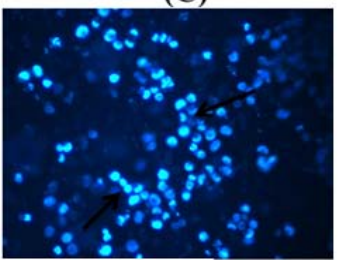

(F)

Fig. 7: A0/EB and DAPI staining of K562 cells treated with $\mathrm{IC}_{50}$ conc. of $B M$ MeOH and AQE extracts for $48 \mathrm{~h}$ and images were captured under 20 X magnification. A): In AO/EB staining untreated K562 cells showed green fluorescence. B): BM MeOH and C): AQE extracts treated $\mathrm{K} 562$ cells undergoing apoptosis (represented by an arrow mark) appeared as an orange colour. D): In DAPI staining untreated K562 cells visualized as normal blue colour whereas E): BM MeOH and F): AQE extracts treated K562 cells undergoing DNA fragmentation (represented by an arrow mark) showed more intensity in blue colour 


\section{Cell cycle analysis}

PI is used as a DNA stain in flow cytometry to evaluate cell viability or DNA content in cell cycle analysis. It is useful for differentiating necrotic (or) apoptotic and normal cells [35]. To determine whether the $\mathrm{MeOH}$ and $\mathrm{AQE}$ extracts of $B M$ induced cell cycle arrest in the K562 cells, the DNA content was measured by
FACS using PI staining. There was a significant increase in SubGo population to 51.26 (fig. 8C) and 18.15 (fig. 8B) in K562 cells treated with $\mathrm{AQE}$ and $\mathrm{MeOH}$ extracts of $\mathrm{BM}$. Concomitantly, a decrease in $\mathrm{G}_{0} / \mathrm{G}_{1}$ (from 63.04 to 38.93 and 53.04 ) and $\mathrm{S}$ phases (from 24.73 to 6.20 and 13.67) for $\mathrm{AQE}$ and $\mathrm{MeOH}$ extracts of $B M$ was observed. The results confirmed that K562 cells upon treatment of $B M$ extracts induce apoptosis.

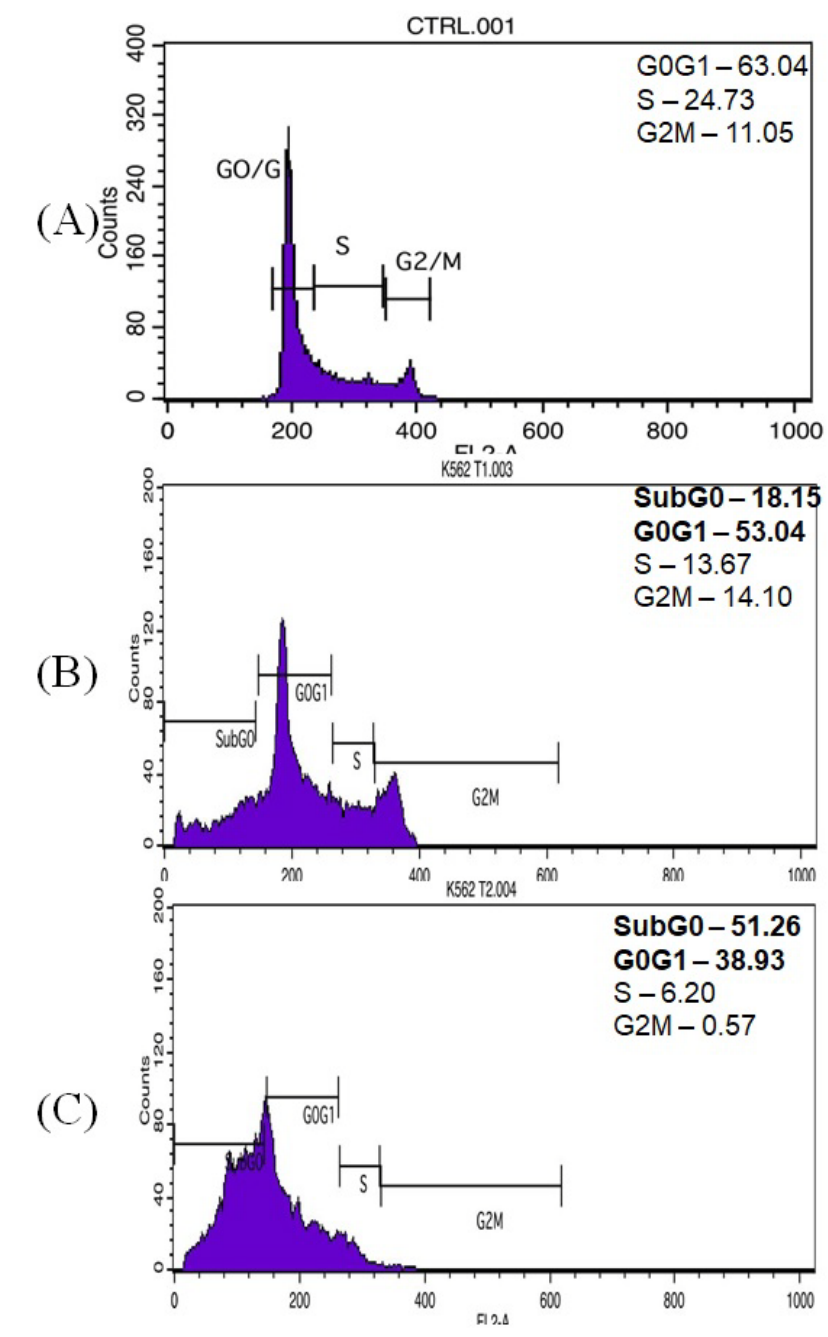

Fig. 8: Cell cycle analysis of $B M$ extracts treated $K 562$ cells. A): K562 untreated cells. B): induction of apoptosis (sub-Go phase) by $B M$ $\mathrm{MeOH}, \mathrm{C}$ ): AQE extracts for $48 \mathrm{~h}$ revealed by PI staining

\section{CONCLUSION}

Plants are being investigated extensively for their pharmacological purpose as potent anti-cancer drugs. In the present study, $B M \mathrm{MeOH}$ and AQE crude extracts were being used to examine their cytotoxicity towards CML cell line. Secondary metabolites like phenols and flavonoids were estimated. TPC was more in AQE extract than the $\mathrm{MeOH}$ extract of $B M$. TFC was high in $\mathrm{MeOH}$ extract of $B M$ compared to AQE extract of $B M$. GC MS analysis revealed nine important phytoconstituents in $\mathrm{MeOH}$ and $\mathrm{AQE}$ extracts of $B M$. In vitro cytotoxicity of these extracts was tested against K562 cells. $\mathrm{AO} / \mathrm{EB}$ staining, DAPI staining and cell cycle analysis revealed that $\mathrm{AQE}$ extract is more potent than the $\mathrm{MeOH}$ extract of $B M$ in inducing apoptosis in K562 cells. Further studies are required to provide more comprehensive data on the anti-CML activity of the AQE and $\mathrm{MeOH}$ extracts of $B M$.

\section{ACKNOWLEDGEMENT}

We acknowledge Dr. N. Ayyappan-Researcher and Dr. Raphael Mathevet-Head of Dept. of Ecology, IFP, Puducherry for authenticating $B M$ plant sample. We are grateful to the Dept. of Science and Technology (DST), Sophisticated Analytical Instrument Facility (SAIF), IIT Madras for carrying out GC MS analysis. We thank the Dept. of Biotechnology, IIT Madras for assisting with cell cycle analysis.

\section{AUTHORS CONTRIBUTIONS}

All authors equally contributed to drafting the paper. All authors have read and approved the final manuscript.

\section{ABBREVIATION}

methanol-MeOH, aqueous-AQE, Benkara malabarica (Lam.) Tirveng- $B M$, gas chromatography mass spectrometry-GC MS, 3-(4,5Dimethylthiazol-2-yl)-2,5-diphenyltetrazolium bromide-MTT, acridine orange-AO, ethidium bromide-EB, 4',6-diamidino-2phenylindole-DAPI, fluorescence-activated cell sorting-FACS, world health organization-WHO, chronic myeloid leukemia-CML, Philadelphia chromosome- $\mathrm{Ph}$, mitogen activated protein kinaseMAPK, signal transducers and activator of transcription-STAT, 
phosphoinositide-3-kinase-PI3K, tyrosine kinase inhibitors-TKIs, food and drug administration-FDA, multi-drug resistance-MDR, pglycoprotein-p-gp, national centre for cell sciences-NCCS, fetal bovine serum-FBS, French institute of Pondicherry-IFP, Total phenolic content-TPC, concentration-conc, folin-ciocalteu-FC, room temperature-RT, gallic acid equivalents-GAE, total flavonoid content-TFC, quercetin equivalents-QE, national institute of standards and technology-NIST, dimethyl sulphoxide-DMSO, phosphate buffer saline-PBS, propidium iodide-PI, standard deviation-SD, analysis of variance-ANOVA, double-stranded-ds, department of science and technology-DST and sophisticated analytical instrument facility-SAIF.

\section{CONFLICTS OF INTERESTS}

The authors declare that they have no conflict of interest

\section{REFERENCES}

1. Watt E, Pretorius CJ. Purification and identification of active components of Carpobrotus edulis L. J Ethnopharmacol 2001;76:87-91.

2. Seyyednejad SM, Motamedi H. A review on native medicinal plants in Khuzestan, Iran with antimicrobial properties. Int J Pharmacol 2010;6:551-60.

3. Kalaichelvi K, Sharmila S, Dhivya SM. In vitro antioxidant and antiulcerogenic activity of Cayratia pedata Var. glabra against experimentally induced gastric lesions in Wistar strain Albino rats. Asian J Pharm Clin Res 2018;11:105-10.

4. Ozben T. Oxidative stress and apoptosis: impact on cancer therapy. J Pharm Sci 2007;96:2181-96.

5. Ravindran AE, Thoppil JE. Phytochemical profiling and antibacterial efficacy screening of Aglaia malabarica Sasidh. Int J Curr Pharm Res 2018;10:20-2.

6. Baker JT, Borris RP, Carte B, Cordell GA, Soejarto DD, Cragg GM, et al. Natural product drug discovery and development: a new perspective on international collaboration. J Nat Prod 1995;58:1325-57.

7. Nair R, Kalariya T, Chanda S. Antibacterial activity of some selected Indian medicinal flora. Turk J Biol 2005;29:41-7.

8. Sianipar MP, Suwarso E, Rosidah R. Antioxidant and anticancer activities of hexane fraction from Carica papaya L. male flower. Asian J Pharm Clin Res 2018;11:81-3.

9. Pluk H, Dorey K, Superti-Furga G. Autoinhibition of c-Abl. Cell 2002;108:247-59.

10. Lenaerts T, Pacheco JM, Traulsen A, Dingli D. Tyrosine kinase inhibitor therapy can cure chronic myeloid leukemia without hitting leukemic stem cells. Haematologica 2010;95:900-7.

11. Puissant A, Dufies M, Fenouille N, Ben-Sahra I, Jacquel A, Robert $\mathrm{G}$, et al. Imatinib triggers the mesenchymal-like conversion of CML cells associated with increased aggressiveness. J Mol Cell Biol 2012;4:207-20.

12. Melda C, Yusuf B, Guray S. Changes in molecular biology of chronic myeloid leukemia in tyrosine kinase inhibitor era. Am J Blood Res 2013;3:191-200.

13. Sacha T. Imatinib in chronic myeloid leukemia: an overview. Mediterranean J Hematol Infectious Diseases 2014;6: e2014007.

14. Akard LP. Second-generation BCR-ABL kinase inhibitors in CML. N Engl J Med 2010;363:1672-3.

15. Shamroe CL, Comeau JM. Ponatinib: a new tyrosine kinase inhibitor for the treatment of chronic myeloid leukemia and philadelphia chromosome-positive acute lymphoblastic leukemia. Ann Pharmacother 2013;47:1540-6.

16. Chapter in a book: Khajapeer KV, Baskaran R. Natural products for the treatment of Chronic myeloid leukemia. In: Bankovic J. editor. Anti-cancer drugs-nature, synthesis and cell. $1^{\text {st }}$ ed. Croatia: Intech publications; 2016. p. 1-48.
17. Lozzio CB, Lozzio BB. Human chronic myelogenous leukemia cell-line with positive Philadelphia chromosome. Blood 1975;45:321-34.

18. Drexler HG, MacLeod RAF, Uphoff CC. Leukemia cell lines: in vitro models for the study of Philadelphia chromosomepositive leukemia. Leuk Res 1999;23:207-15.

19. Jayasinghe UL, Jayasooriya CP, Bandara BM, Ekanayake SP, Merlini L, Assante G. Antimicrobial activity of some Sri Lankan Rubiaceae and Meliaceae. Fitoterapia 2002;73:424-7.

20. Mishra N, Oraon A, Dev A, Jayaprakash V, Basu A, Pattnaik AK, et al. Anticonvulsant activity of Benkara malabarica (Linn.) root extract: in vitro and in vivo investigation. J Ethnopharmacol 2010;128:533-6.

21. Bali EB, Acik L, Akca G, Sarper M, Elci MP, Avcu F, et al. Antimicrobial activity against periodontopathogenic bacteria, antioxidant and cytotoxic effects of various extracts from endemic Thermopsis turcica. Asian Pac J Trop Biomed 2014;4:505-14.

22. Akanni O0, Owumi SE, Adaramoye OA. In vitro studies to assess the antioxidative, radical scavenging and arginase inhibitory potentials of extracts from Artocarpus altilis, Ficus exasperate and Kigelia africana. Asian Pac J Trop Biomed 2014;4 Suppl 1:S492-9.

23. Khajapeer KV, Krishna PP, Baskaran R. GC MS and elemental analysis of Cinnamomum tamala. Int J Pharm Pharm Sci 2015;7:398-402.

24. Mosmann T. Rapid colorimetric assay for cellular growth and survival: application to proliferation and cytotoxicity assays. J Immunol Methods 1983;65:55-63.

25. Machana S, Weerapreeyakul N, Barusrux S, Thumanu K, Tanthanuch W. Synergistic anticancer effect of the extracts from Polyalthia evecta caused apoptosis in human hepatoma (HepG2) cells. Asian Pac J Trop Biomed 2012;2:589-96.

26. Sheng Y, Pero RW, Amiri A, Bryngelsson C. Induction of apoptosis and inhibition of proliferation in human tumor cells treated with extracts of Uncaria tomentosa. Anticancer Res 1998;18:3363-8.

27. Kennedy RK, Veena V, Naik PR, Lakshmi P, Krishna R, Sudharani S, et al. Phenazine-1-carboxamide (PCN) from Pseudomonas sp. strain PUP6 selectively induced apoptosis in the lung (A549) and breast (MDA MB-231) cancer cells by inhibition of antiapoptotic Bcl-2 family proteins. Apoptosis 2015;20:858-68.

28. Veena VK, Popavath RN, Kennedy K, Sakthivel N. In vitro antiproliferative, pro-apoptotic, antimetastatic and antiinflammatory potential of 2,4-diacteylphloroglucinol (DAPG) by Pseudomonas aeruginosa strain FP10. Apoptosis 2015;20:1281-95.

29. Marinova D, Ribarova F, Atanassova M. Total phenolics and total flavonoids in Bulgarian fruits and vegetables. J Chem Technol Metall 2005;40:255-60.

30. Katalinic V, Milos M, Kulisic T, Jukic M. Screening of 70 medicinal plant extracts for antioxidant capacity and total phenols. Food Chem 2006;94:550-7.

31. Williams RJ, Spencer JP, Rice-Evans C. Flavonoids: antioxidants or signalling molecules? Free Radical Biol Med 2004;36:838-49.

32. Romagnolo DF, Selmin OI. Flavonoids and cancer prevention: a review of the evidence. J Nutr Gerontol Geriatr 2012;31:20638.

33. Kuan L, Peng-cheng L, Run L, Xing W. Dual AO/EB staining to detect apoptosis in osteosarcoma cells compared with flow cytometry. Med Sci Monit Basic Res 2015;21:15-20.

34. Kapuscinski J. DAPI: a DNA-specific fluorescent probe. Biotech Histochem 1995;70:220-33.

35. Lecoeur H. Nuclear apoptosis detection by flow cytometry: influence of endogenous nucleases. Exp Cell Res 2002;7:1-14. 